\title{
MEASUREMENT OF CARDIAC OUTPUT IN MAN USING THE TECHNIQUE OF CATHETERIZATION OF THE RIGHT AURICLE OR VENTRICLE
}

\author{
By A. COURNAND, R. L. RILEY, E. S. BREED, E. DEF. BALDWIN, AND \\ D. W. RICHARDS, JR., WITH THE TECHNICAL ASSISTANCE OF \\ M. S. LESTER AND M. JONES \\ (From the Department of Medicine of Columbia University, College of Physicians and Surgeons, and \\ the Tuberculosis Service, Bellevue Hospital (Columbia University Division), New York City)
}

(Received for publication June 27,1944 )

Determination of cardiac output on the basis of the so-called Fick principle requires the measurement of oxygen or of carbon dioxide content of arterial blood, and of mixed venous blood, and the total oxygen intake or carbon dioxide elimination by the lungs, per unit of time. With these values, cardiac output is obtained from either of the following two equations:

(a) Cardiac output (ml. per minute)

$$
\begin{aligned}
= & \frac{\mathrm{O}_{2} \text { intake, } \mathrm{ml} \text {. per minute }}{\text { Arterial } \mathrm{O}_{2} \text {, volumes per cent }} \times 100 \\
& - \text { venous } \mathrm{O}_{2} \text {, volumes per cent }
\end{aligned}
$$

(b) Cardiac output (ml. per minute)

$$
\begin{gathered}
=\frac{\mathrm{CO}_{2} \text { output, ml. per minute }}{\text { Venous } \mathrm{CO}_{2}, \text { volumes per cent }} \\
- \text { arterial } \mathrm{CO}_{2} \text {, volumes per cent }
\end{gathered}
$$

The practical difficulty preventing the ready application of this principle in human subjects has been that of obtaining reliable samples of average or mixed venous blood. With the development of the technique of catheterization of the right heart (1), this difficulty has been largely overcome; and the experience of the last 3 years has led to a procedure for determining cardiac output in man which can be used in almost all forms of disease or injury, with safety and without discomfort to the patient, beyond that attendant upon the insertion of a needle in the femoral artery, and cutting down on a median basilic vein, both under novocaine anesthesia. In the present paper, this method of cardiac output measurement is described in detail, its validity is discussed, and the results in a group of 33 "normal" hospital control subjects reported.

\section{A. Catheterization of the right heart}

A No. 8 or No. 9 ureteral catheter is used, having a single opening at the tip and a special air-tight adapter at the base for a Luer syringe. 1 For convenience in manipulation, a slight curve is provided in the distal 3 inches of the catheter. A single opening at the tip was found to be preferable to multiple openings.

A sufficiently large vein is chosen in the antecubital fossa to ensure easy passage of the catheter. Either arm may be used. This vein should lead into the brachial vein system, not the cephalic. After local novocainization, the vein is exposed, using careful aseptic surgical technique, making as small an incision as feasible. Two No. $\mathrm{C}$ silk ligatures are passed under the vein. The distal one is tied with a single knot to prevent back bleeding, when the vein is opened. The proximal ligature is clamped and is used as a sling to pull the vein taut when necessary to occlude its lumen above the point of incision.

A transverse nick is then made in the vein wall with a bayonet-bladed scalpel. The proximal lip of the opening is caught in a fine hemostat so that the lumen may be held open while the catheter tip is being introduced.

The catheter which has been previously connected to a saline reservoir and standard infusion tubing by a 3-way stopcock, is flushed through and also wiped off with saline. A flow of saline (1 to 2 drops a second) is maintained through the catheter. The tip is then introduced into the vein and pushed up rapidly to the axilla. The catheter should slip in easily, without resistance and without pain or other sensation. All further manipulation is carried out under fluoroscopic control.

The arm is held in internal rotation and the patient's head and neck are inclined as far laterally as possible towards the operative side to prevent entrance of the catheter into the internal jugular vein. Any obstruction met at the axilla will usually be overcome by abducting the arm, or by raising the shoulder girdle headwards, while the catheter is withdrawn a little and advanced again.

The curve in the distal end of the catheter, as previously described, does not influence the flexibility of the whole system and is helpful in correcting false routes which may be taken by the catheter tip. Of these, the most frequent

1 This catheter has been specially designed and provided by the United States Catheter and Instrument Corporation, Glens Falls, New York. 
is passage upward into the internal jugular vein. If the end of the catheter goes into this vein, partial withdrawal and rotation of the curved tip with subsequent reinsertion will usually direct the catheter downward into the auricle. If slight pain or veno-constriction develops at the point of introduction of the catheter into the basilic vein, as a result of withdrawal, rotation, and other manipulation, these are usually overcome by infiltration of the perivenous tissue with novocaine.

\section{B. Position of catheter in auricle or ventricle}

When the catheter tip has passed beyond the jugular vein, further insertion usually proceeds without resistance, and is continued until the catheter tip is seen fluoroscopically to rest in the right auricle, about 1 or $2 \mathrm{~cm}$. above the edge of the diaphragmatic shadow. The catheter should be rotated so that the tip points medially, i.e., toward the tricuspid valve. This is the optimal auricular position. Anteroposterior and lateral x-rays are then taken to record the position of the catheter in the heart. In Figure 1, a number of anteroposterior and lateral $\mathrm{x}$-rays illustrate $(a)$ optimum as well as $(e)$ undesirable positions in the right auricle, (b) location in the right ventricle, $(d)$ superior vena cava, and $(c)$ inferior vena cava.

If it is desired to catheterize the right ventricle, attempts are made to direct the tip towards the left and across the midline, by allowing sufficient length of the catheter to be introduced in the vein, so that the tip may move with the blood stream through the tricuspid valve. The position of the catheter in the right ventricle can be verified by connecting the catheter with a saline manometer, which will show pulsations of the order of 10 to $20 \mathrm{~mm} . \mathrm{H}_{2} \mathrm{O}$,
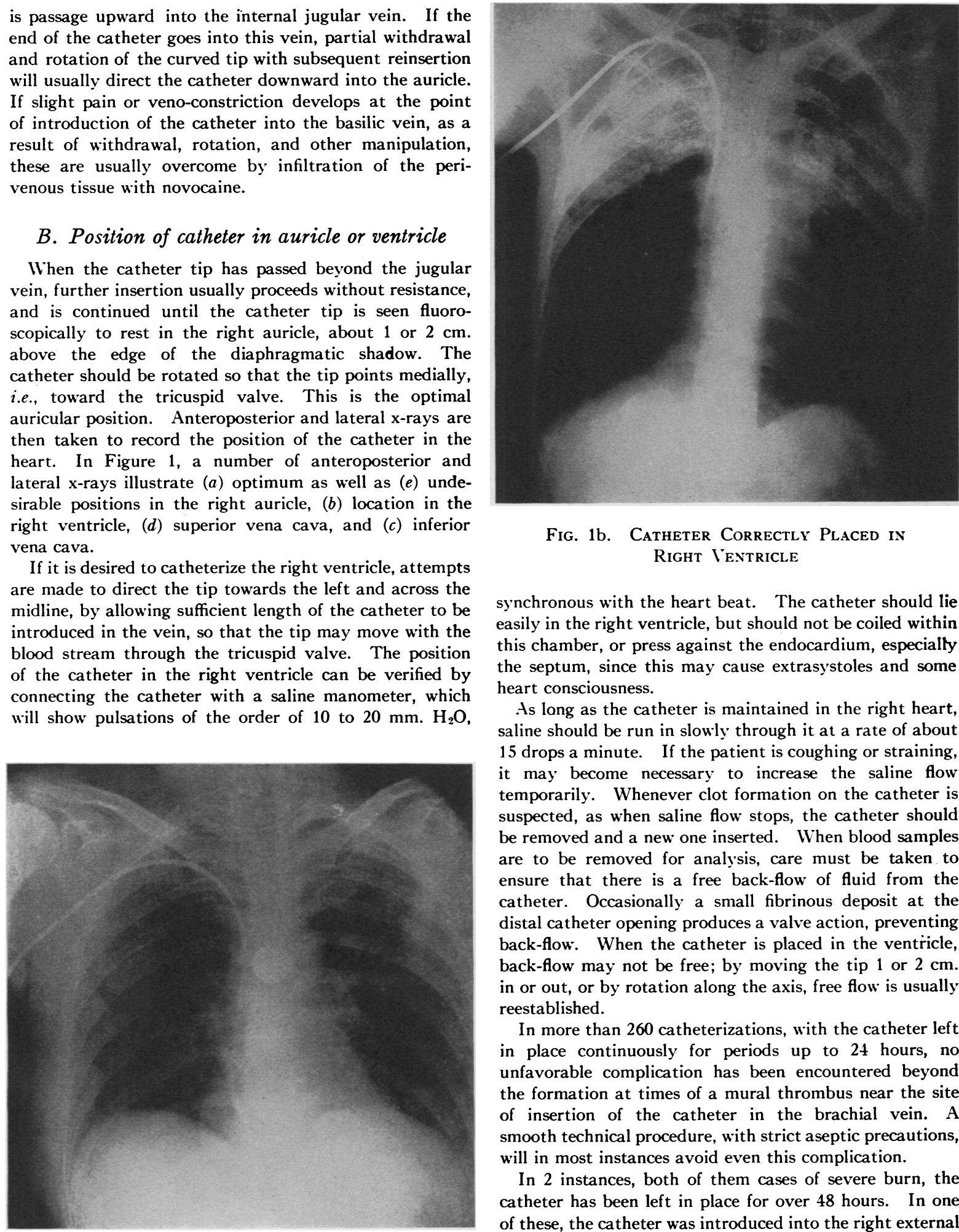

Fig. 1b. Catheter Correctly Placed in Right Ventricle

synchronous with the heart beat. The catheter should lie easily in the right ventricle, but should not be coiled within this chamber, or press against the endocardium, especially the septum, since this may cause extrasystoles and some heart consciousness.

As long as the catheter is maintained in the right heart, saline should be run in slowly through it at a rate of about 15 drops a minute. If the patient is coughing or straining, it may become necessary to increase the saline flow temporarily. Whenever clot formation on the catheter is suspected, as when saline flow stops, the catheter should be removed and a new one inserted. When blood samples are to be removed for analy'sis, care must be taken to ensure that there is a free back-flow of fluid from the catheter. Occasionally a small fibrinous deposit at the distal catheter opening produces a valve action, preventing back-flow. When the catheter is placed in the ventricle, back-flow may not be free; by moving the tip 1 or $2 \mathrm{~cm}$. in or out, or by rotation along the axis, free flow is usually reestablished.

In more than 260 catheterizations, with the catheter left in place continuously for periods up to 24 hours, no unfavorable complication has been encountered beyond the formation at times of a mural thrombus near the site of insertion of the catheter in the brachial vein. A smooth technical procedure, with strict aseptic precautions, will in most instances avoid even this complication.

In 2 instances, both of them cases of severe burn, the catheter has been left in place for over 48 hours. In one of these, the catheter was introduced into the right external jugular vein; in the other, into the left median basilic vein. Both patients ultimately died as a result of the burns, and were found at autopsy to have small thrombi in one of the 


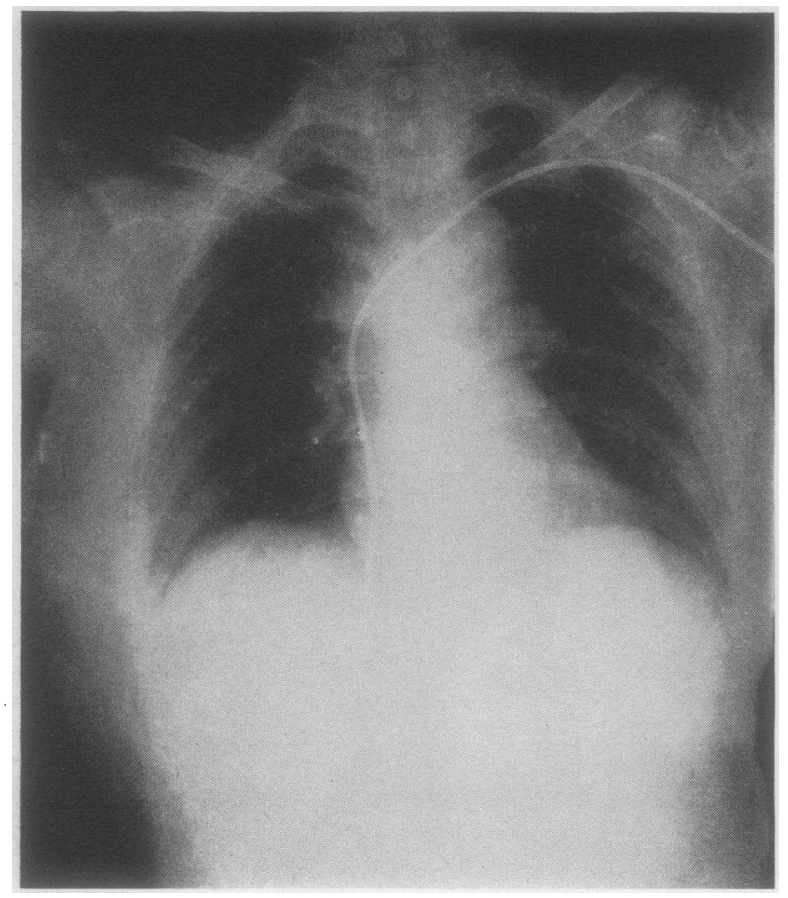

Fig. 1c. Catheter Too Low, Tip in Inferior Vena Cava

great veins traversed by the catheter. It should be noted that both were cases where the catheterization was accomplished only with great difficulty, and with definite contamination of the surgical field. Under the circumstances, the catheter afforded the only means of administering plasma and other fluids. Pathological study of the gross specimen of the auricular and ventricular wall, and serial section, especially of the tricuspid valve, were made in a number of cases; they failed to reveal any damage to the endocardium or valve leaflets. In 1 of the 2 cases above described, where the catheter was left in place more than 48 hours, a small pulmonary infarct was found at autopsy. This was the only instance of pulmonary infarction.

A point of some importance, though not directly concerned with cardiac output determination, is that we have from the beginning endeavored to hold to the principle that no injections be made through the catheter directly into the heart, except for non-irritant fluids such as saline, plasma, or whole blood.

\section{Cannulization of the femoral artery}

A special form of needle is used for this purpose. This is a Lindeman-type, in which a medium bevel No. 22 needle fits into a No. 19 outer sleeve, with blunt tip. The collar at the base of the needle is soldered about 1.5 $\mathrm{cm}$. down the No. 19 shaft, leaving the base of this shaft projecting backwards free from the collar. When a Luerlock syringe is attached for sampling, this free segment goes directly into the end of the syringe, and contamination from blood or blood-clot lying in the needle-collar is thus avoided.

In preparing the patient, the skin over the femoral artery is sterilized, the local region novocainized, and the needle inserted into the femoral artery, then strapped in place with adhesive. With the usual precautions, especially avoiding flexion of the thigh or motion of the hip joint, a hematoma rarely develops, and has never been of any serious consequence.

\section{Expired air}

Expired air is collected and measured in a Tissot spirometer or Douglas bag. A rubber mouthpiece and noseclip are usually satisfactory, but it was frequently found necessary to hold the patient's lips tightly around the mouthpiece. The spirometer or Douglas bag is first washed out with expired air for a few minutes; the patient being thus acquainted with the procedure. This sample is then discarded.

\section{E. Procedure}

A period of at least 30 minutes of absolute quiet, following insertion of catheter and needle, during which respiration and pulse are repeatedly counted, should be provided before the Fick procedure is started. Expired air is collected over an accurately measured interval from 1 to 2 minutes, or longer if desired, and if the subject is quiet. Fifteen seconds after the start of the expired air

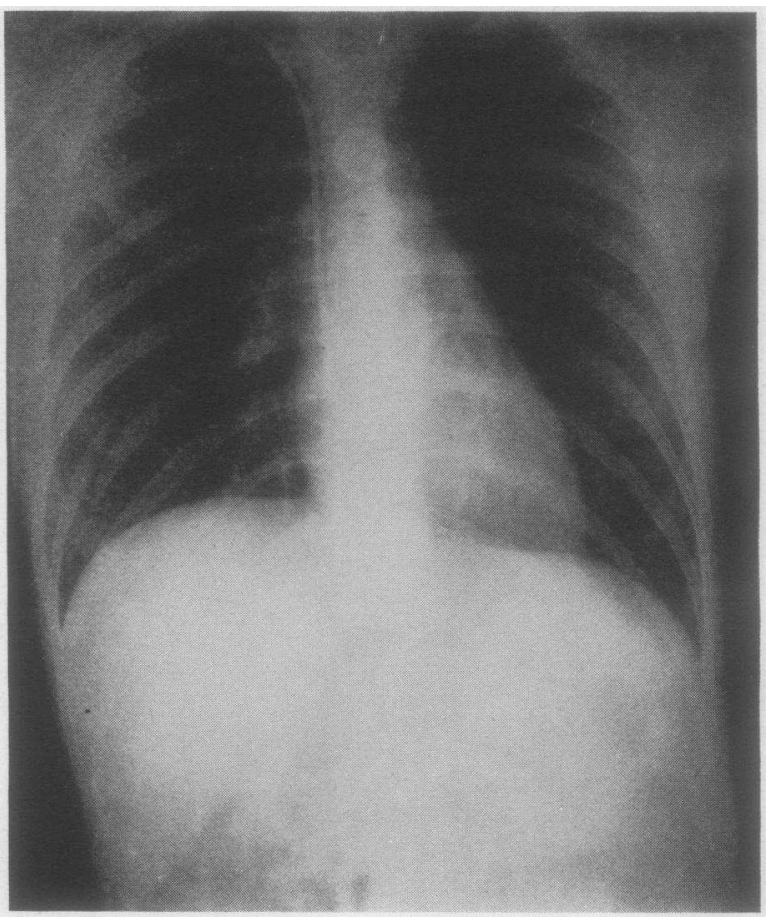

Fig. 1d. Catheter Too High, Tip in Superior Vexa Cava 


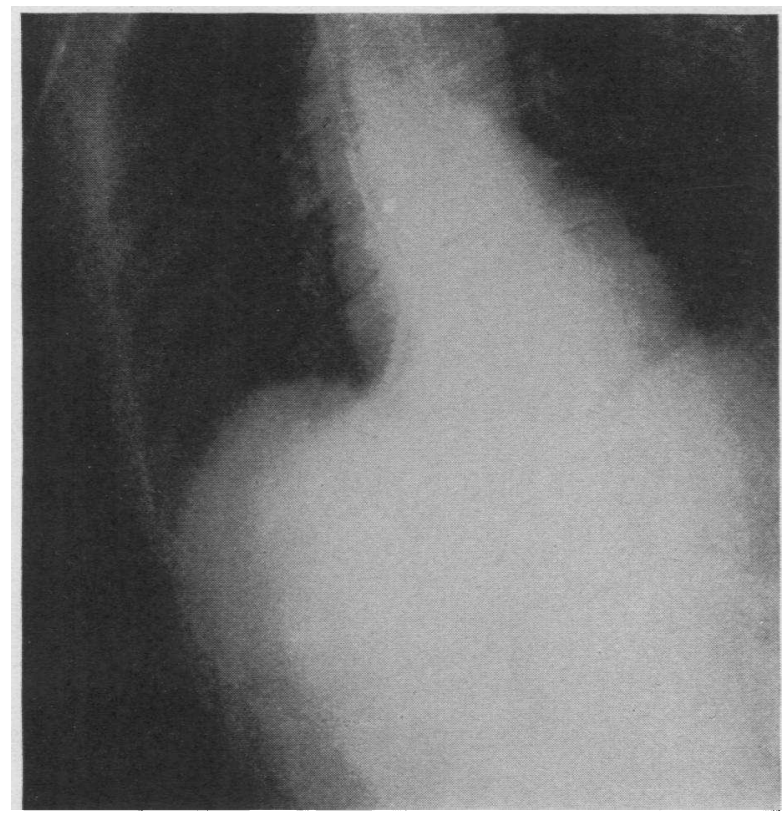

Fig. 1e. Catheter Tip Improperly Placed, Lying Against lateral Auricular Wall

collection, mixed venous blood sampling is begun, followed 15 seconds later by arterial blood sampling. Each blood sample requires about 25 seconds to collect, and the sampling is thus spread out over a considerable part of the air collection period. The importance of the utmost care in obtaining samples, and in the smooth running of the research team, cannot be overemphasized, both for the reliability of the data, and the relaxation and composure, and maintenance of the "steady state" of the patient.

\section{F. Collection of samples}

(1) Mixed venous blood. The saline in the catheter is first flushed out by withdrawing 5 to $10 \mathrm{ml}$. of blood back through it in a $20 \mathrm{ml}$. syringe. A $15 \mathrm{ml}$. sample of mixed venous blood is then taken under $5 \mathrm{ml}$. of oil in another syringe. Air contamination is excluded by a tight rubber adapter and a Luer-lock connection. (2) Arterial blood. This is similarly collected in an oil-containing syringe attached directly through Luer-lock connection to the indwelling arterial needle. Both samples are immediately transferred after needle connection to iced blood bottles containing $10 \mathrm{ml}$. of oil, previously boiled to remove the air, and crystals of anticoagulant $(0.6 \mathrm{mgm}$. sodium fluoride and $4.5 \mathrm{mgm}$. neutral potassium oxalate dried in autoclave). They are stirred slowly to prevent settling of red blood cells, taken directly to the laboratory, and the blood analyzed immediately for oxygen and carbon dioxide. More recently, blood has been collected into a syringe, the wall of which had been previously moistened with one drop of heparin solution (liquaemin); mercury was used as a seal and small rubber connections obturated with a glass rod permit the filling of pipettes after a preliminary period of rotation.

\section{G. Analyses of samples}

Carbon dioxide and oxygen contents of mixed venous blood and arterial blood are done in duplicate on the Van Slyke-Neill apparatus. In addition, in the series here reported, oxygen capacity determination, and $\mathrm{pH}_{\mathrm{s}}$ measurement, using the glass electrode, were made, in both arterial and mixed venous blood samples. Expired air samples were analyzed in the Haldane apparatus, to determine oxygen intake and carbon dioxide output per minute.

\section{H. Example of calculation}

S. B. Age 36 years. Weight 86 kgm. Body surface area 1.98 sq. $m$.

Carbon dioxide output, $m l$. per minute $=211$

Oxygen intake, $m l$. per minute $=289$

R.Q. $=\frac{211}{289}=0.73$

Arterial blood carbon dioxide content, volumes per cent $=45.5$

Arterial blood oxygen content, volumes per cent $=19.6$

Mixed venous blood oxygen content, volumes per cent $=15.3$

Mixed venous blood carbon dioxide content, volumes per cent $=48.7$

Carbon dioxide arterio-venous difference, volumes per cent $=3.2$

Oxygen arterio-venous difference, volumes per cent $=4.3$

Blood R.Q. $=\frac{3.2}{4.3}=0.74$

Cardiac output from carbon dioxide data, in liters per minute $=\frac{211}{3.2 \times 10}=6.60$

Cardiac output from oxygen data, in liters per minute $=\frac{289}{4.3 \times 10}=6.72$

Average cardiac output $=6.66$

Pulse rate $=104$

Stroke volume $=\frac{6.66}{104}=64$

Cardiac index (cardiac output in liters per minute per sq. $m$. body surface) $=3.36$

Cardiac output per $100 \mathrm{ml}$. of oxygen intake in liters $=\frac{6.66}{289} \times 100=2.30$

Cardiac output per kgm. of weight in $m l .=\frac{6.66}{86}=77.5$

As will be indicated below, the cardiac output calculated from the oxygen data is the more reliable figure.

\section{Validity of the method}

(1) Comparison between blood from the right auricle and from the right ventricle.

The fundamental assumption upon which the present application of the "direct Fick" principle 
TABLE I

Comparison of respiratory gases in blood samples taken successively from right ventricle and right auricle

\begin{tabular}{|c|c|c|c|c|c|c|c|c|c|}
\hline \multirow{2}{*}{ Name } & \multirow{2}{*}{ Diagnosis } & \multirow{2}{*}{ Date } & \multicolumn{2}{|c|}{$\begin{array}{c}\text { Right } \\
\text { ventricular } \\
\text { blood }\end{array}$} & \multicolumn{2}{|c|}{$\begin{array}{c}\text { Right } \\
\text { auricular } \\
\text { blood }\end{array}$} & \multicolumn{2}{|c|}{$\begin{array}{c}\text { Difference } \\
\text { ventricular- } \\
\text { auricular }\end{array}$} & \multirow{2}{*}{$\begin{array}{c}\text { Time } \\
\text { interva }\end{array}$} \\
\hline & & & $\mathrm{CO}_{2}$ & $\mathrm{O}_{2}$ & $\mathrm{CO}_{2}$ & $\mathrm{O}_{2}$ & $\mathrm{CO}_{2}$ & $\mathrm{O}_{2}$ & \\
\hline & & & \multicolumn{2}{|c|}{ volumes per cent } & \multicolumn{2}{|c|}{ volumes per cent } & \multicolumn{2}{|c|}{ volumes per cent } & minutes \\
\hline E. P. & Normal & $3 / 18 / 42$ & 51.6 & 13.4 & 52.3 & 13.5 & -0.7 & -0.1 & \\
\hline I. M. & Normal & $2 / 3 / 43$ & 52.5 & 12.0 & 51.1 & 13.2 & +1.4 & -1.2 & \\
\hline & & $2 / 11 / 43$ & 54.3 & 10.8 & 54.1 & 10.7 & +0.2 & +0.1 & 6 \\
\hline J. H. & Pulm. fibrosis, emphysema & $4 / 27 / 43$ & 65.1 & 12.5 & 63.5 & 12.3 & +1.6 & +0.2 & 5 \\
\hline I. M. & Pulm. tbc., cor pulmonale, arthritis & $5 / 4 / 43$ & 53.7 & 11.1 & 53.5 & 10.9 & +0.2 & +0.2 & 3 \\
\hline M. M. & Suppurative dis., rt. lung & $5 / 7 / 43$ & 53.0 & 10.1 & 52.9 & 10.1 & +0.1 & 0 & 3 \\
\hline H. Y. & Chr. pulm. tbc., fibrosis, emphysema & $5 / 20 / 43$ & 46.9 & 15.7 & 46.7 & 15.8 & +0.2 & +0.1 & 2.5 \\
\hline R.S. & Arterial hypertension & $11 / 23 / 43$ & 45.8 & 15.6 & 46.3 & 15.5 & -0.5 & +0.1 & \\
\hline & & $1 / 13 / 43$ & 53.9 & 11.4 & 53.7 & 11.3 & +0.2 & +0.1 & \\
\hline M. B. & Hypertension & $1 / 11 / 43$ & 66.5 & 11.6 & 66.4 & 11.5 & +0.1 & +0.1 & \\
\hline C. B. & Hypertension & $1 / 19 / 43$ & 55.2 & 6.5 & 53.5 & 6.5 & +1.7 & 0 & \\
\hline F.S. & Tricuspid insufficiency & $4 / 15 / 43$ & 47.0 & 14.1 & 48.5 & 14.0 & -1.5 & +0.1 & 2 \\
\hline L. S. & Arteriosclerotic heart dis. & $4 / 20 / 43$ & 58.3 & 16.5 & 59.9 & 16.4 & -1.6 & +0.1 & 1.5 \\
\hline I. IV. & Intestinal obstruction & $3 / 3 / 43$ & 79.4 & 6.9 & 79.2 & 7.0 & +0.2 & -0.1 & \\
\hline A. S. & Gastric hemorrhage & $1 / 9 / 43$ & 52.8 & 11.9 & 52.6 & 11.9 & +0.2 & 0 & 4 \\
\hline B. W. & Gastric hemorrhage & $1 / 4 / 43$ & 50.9 & 7.6 & 51.4 & 7.7 & -0.5 & -0.1 & 5 \\
\hline W.B. & Chest injury & $3 / 4 / 43$ & 38.8 & 9.3 & 39.3 & 9.1 & -0.5 & +0.2 & 1 \\
\hline C. LeC. & Head injury & $2 / 13 / 43$ & 39.8 & 9.7 & 39.7 & 9.6 & +0.1 & +0.1 & 5 \\
\hline M. M. & Compound fracture & $10 / 30 / 42$ & 42.8 & 7.4 & 42.8 & 6.8 & 0 & +0.6 & 5 \\
\hline S. R. & Compound fracture & $1 / 18 / 43$ & 50.3 & 14.7 & 50.7 & 15.6 & -0.4 & -0.9 & 4 \\
\hline & & $1 / 18 / 43$ & 49.0 & 14.9 & 48.8 & 14.8 & +0.2 & +0.1 & 5 \\
\hline J. S. & Compound fracture & $1 / 22 / 43$ & 56.2 & 10.2 & 54.1 & 10.5 & +2.1 & -0.3 & 5 \\
\hline & Compound fracture & $1 / 26 / 43$ & 43.9 & 10.3 & 43.8 & 10.1 & +0.1 & +0.2 & 3 \\
\hline W. H. & Compound fracture & $3 / 15 / 43$ & 54.5 & 11.6 & 54.1 & 11.3 & +0.4 & +0.3 & 2 \\
\hline J. O'L. & Fractured pelvis & $5 / 13 / 43$ & 53.5 & 10.2 & 53.3 & 10.4 & +0.2 & -0.2 & 2 \\
\hline J. M. & Comminuted fracture of the femur & $5 / 19 / 43$ & 42.6 & 9.4 & 44.9 & 9.6 & -2.3 & -0.2 & 3 \\
\hline
\end{tabular}

of determining cardiac output is based, rests upon the validity of the auricular sample as representative of true "mixed venous" blood. Evidence has recently been presented to the effect that in dogs, right auricular blood may be different from right ventricular blood (2). In this work, however, no mention is made of the exact position of the catheter in the right auricle, or of any x-ray control of this position.

In 22 subjects, samples of blood were taken successively within a few minutes' time from the right ventricle and then, by withdrawing the catheter a few $\mathrm{cm}$., from the auricle. The exact location of the tip of the catheter in the auricle was ascertained by fluoroscopy and in most instances by $x$-ray films. Table I gives the results of separate analysis of blood $\mathrm{CO}_{2}$ and $\mathrm{O}_{2}$ contents in 22 cases, with differences observed between both sets of samples. The average difference, regardless of sign, between ventricular and auricular samples was, for carbon dioxide, 0.42 volumes per cent, and for oxygen, 0.26 volumes per cent. The range of differences for carbon dioxide was from -0.7 to +2.3 volumes per cent, and for oxygen, from -1.2 to +0.6 volumes per cent. In 19 out of 22 double determinations, the difference between ventricular and auricular $\mathrm{O}_{2}$ content was 0.3 volumes per cent or less. In 1 instance, the difference was +0.6 volumes per cent, and in the 2 remaining cases where the difference was highest, a repeated determination in the same subject, either the same day or at a later date, provided excellent checks. In general, the comparison of oxygen content, in both ventricular and auricular samples, supports the assumption that the auricular sample is truly representative of mixed venous blood. The greater discrepancy between carbon dioxide contents of ventricular and auricular blood is not unexpected; since it is known that blood $\mathrm{CO}_{2}$ values are continually changing, in response to slight alterations in respiratory or circulatory equilibrium. In one-half of the cases, however, the $\mathrm{CO}_{2}$ content difference between samples is within the error of the technique of gas analysis. It was observed that 
with ventricular samples, the blood R.Q., i.e., $\mathrm{CO}_{2} \mathrm{~A}-\mathrm{V}$ diff. $\mathrm{O}_{2} \mathrm{~A}-\mathrm{V}$ diff. gas R.Q. (as calculated from the expired air sample), any better than with auricular samples. In a previous report (1), the argument has been offered that a close check between blood R.Q. and respiratory gas R.Q. is a good indication of an accurate experimental technique. With present evidence, this argument no longer appears valid; and we are using only the oxygen data for actual cardiac output calculation.

(2) Comparison between samples taken at various levels in the right auricle.

In 7 subjects, 2 successive samples were taken: (1) at the optimum position, with the tip of the catheter placed immediately above the diaphragm, and turned toward the left, and (2) about $4 \mathrm{~cm}$. nearer the superior vena cava. The average difference, regardless of sign, between the 2 auricular samples was, for carbon dioxide, from -2.7 to +0.8 volumes per cent, and for oxygen, from -1.1 to +0.4 volumes per cent. In 3 out of 7 determinations, both samples checked well, but in the remaining 4 , the discrepancy was quite large.

(3) In several subjects, blood was taken from the inferior vena cava and then from the right auricle. Carbon dioxide as a rule tended to be higher and oxygen lower in the inferior vena cava than in the auricle.

The comparative data given above establish the following points:

(a) If the catheter is properly placed in the right auricle, blood samples withdrawn through the catheter represent true "mixed venous" blood.

(b) Blood oxygen contents provide more reliable data, for calculation of cardiac output, than blood $\mathrm{CO}_{2}$ contents, and therefore cardiac output data are calculated only on the basis of oxygen data.

(4) Arterial blood sample. The chief objection that has been raised against arterial blood samples as representing the state of the blood entering the left heart, under the given resting condition of the patient, is that the pain of the arterial puncture momentarily disturbs respiration and circulation. With the use of the indwelling arterial needle, there is usually no pain or sensation when the arterial blood is drawn.

(5) Expired air. A 1- or 2-minute sample of expired air is too brief for accurate measurement of resting oxygen consumption, and some error undoubtedly occurs on this account. However, with seriously ill patients, especially those in shock, a longer period will of ten result in restlessness or even struggling, causing a still greater error.

\section{J. Values of cardiac output in 34 individuals with normal circulation}

Cardiac output has not been measured as yet in a large group of normal healthy individuals in good physical condition. During the past 3 years, however, measurements have been made in 34 individuals with presumably normal circulation (Table II). Seventeen of these were normal healthy males whose state of physical fitness was average. The remaining 17 were patients in the hospital; 10 of them (5 females and 5 males) were suffering from various conditions such as non-active pulmonary tuberculosis or chronic alcoholism, or were convalescent from such conditions as pneumonia, arthritis, or acute pancreatitis; and 7 (6 males and 1 female), previously studied when in a state of peripheral circulatory failure following severe skeletal trauma or burns, were convalescing from these injuries. Age, body size, and weight were scattered over a wide range. This group of 17 cases can be said to represent an average hospital population with relatively normal circulatory function.

The measurements were made under standard conditions, 16 hours after the last meal, and at least 30 minutes after catheter and needle had been in place. Most of these subjects had had no previous experience with the mouthpiece and noseclip used in the collection of expired air. While the procedure did not cause pain, a few of the subjects showed evidence of nervousness.

Of the group of 17 healthy males, 2 had an oxygen consumption somewhat larger than predicted for a state of standard basal metabolism at the time of the determination, and 2 had an elevation of the pulse rate. These 4 cases, listed separately (Table II), are not included in the statistical calculations concerning the various 
TABLE II

Measurements of cardiac output under standard conditions in 34 subjects with normal circulation

\begin{tabular}{|c|c|c|c|c|c|c|c|c|c|c|c|c|c|}
\hline \multirow{2}{*}{ Age } & \multirow{2}{*}{$\begin{array}{l}\text { Body } \\
\text { sur- } \\
\text { face }\end{array}$} & \multirow{2}{*}{ Wt. } & \multirow{2}{*}{$\begin{array}{c}\text { Hemo- } \\
\text { glo- } \\
\text { bin }\end{array}$} & \multirow{2}{*}{$\begin{array}{c}\text { Oxy- } \\
\text { gen, ar- } \\
\text { terio- } \\
\text { venous } \\
\text { diff. }\end{array}$} & \multicolumn{3}{|c|}{ Cardiac output } & \multirow{2}{*}{$\begin{array}{c}\text { Oxy- } \\
\text { gen, in } \\
\text { take }\end{array}$} & \multirow{2}{*}{$\begin{array}{l}\text { Ven- } \\
\text { tila- } \\
\text { tion }\end{array}$} & \multirow{2}{*}{ R.Q. } & \multirow{2}{*}{$\begin{array}{l}\text { Pulse } \\
\text { rate }\end{array}$} & \multirow{2}{*}{$\begin{array}{c}\text { Resp. } \\
\text { rate }\end{array}$} & \multirow{2}{*}{ Comment } \\
\hline & & & & & & & $\begin{array}{c}\text { per } \\
\text { beat }\end{array}$ & & & & & & \\
\hline years & $s q . m$. & kgm. & grams & $\begin{array}{c}\text { vol- } \\
\text { umes } \\
\text { per cent }\end{array}$ & $\mid \begin{array}{c}\text { L. per } \\
\text { min.per } \\
\text { sq. m. }\end{array}$ & $\underset{\substack{\text { ml. } \\
\text { per } \\
\text { kgm. }}}{\text {. }}$. & $m l$. & $\begin{array}{c}\text { ml. per } \\
\text { min.per } \\
\text { sq. m. }\end{array}$ & $\left|\begin{array}{c}\text { L. per } \\
\text { min.per } \\
\text { sq. m. }\end{array}\right|$ & & & & \\
\hline
\end{tabular}

A. 13 normal males under standard basal conditions

\begin{tabular}{|c|c|c|c|c|c|c|c|c|c|c|c|c|c|}
\hline $\begin{array}{l}\text { P. H. } \\
\text { F. K. } \\
\text { W. O'B. } \\
\text { H. W. } \\
\text { W. O. B. } \\
\text { J. B. } \\
\text { J. T. } \\
\text { H. P. } \\
\text { I. M. } \\
\text { O. E. } \\
\text { J.P. } \\
\text { A. H. } \\
\text { P. McK. }\end{array}$ & $\begin{array}{l}52 \\
41 \\
44 \\
37 \\
49 \\
32 \\
21 \\
26 \\
44 \\
32 \\
35 \\
43 \\
39\end{array}$ & $\begin{array}{l}1.80 \\
1.71 \\
1.70 \\
1.74 \\
1.88 \\
1.81 \\
1.82 \\
2.02 \\
1.48 \\
1.97 \\
1.38 \\
1.79 \\
1.77\end{array}$ & $\begin{array}{l}68.0 \\
61.0 \\
56.0 \\
61.0 \\
71.5 \\
68.0 \\
69.5 \\
79.5 \\
49.5 \\
79.0 \\
42.0 \\
65.0 \\
67.0\end{array}$ & $\begin{array}{l}14.8 \\
13.8 \\
14.7 \\
12.7 \\
13.4 \\
14.8 \\
14.5 \\
14.0 \\
12.4 \\
14.8 \\
14.0 \\
13.7 \\
16.4\end{array}$ & $\begin{array}{l}6.0 \\
4.5 \\
4.9 \\
4.5 \\
5.4 \\
4.7 \\
3.5 \\
3.5 \\
4.3^{*} \\
3.6^{*} \\
4.4 \\
4.0^{*} \\
5.2\end{array}$ & $\begin{array}{l}2.12 \\
3.55 \\
3.17 \\
3.14 \\
2.71 \\
2.91 \\
4.01 \\
3.38 \\
2.93 \\
3.54 \\
2.75 \\
3.47 \\
2.86\end{array}$ & $\begin{array}{r}56.5 \\
99.0 \\
96.0 \\
89.5 \\
71.5 \\
77.5 \\
104.5 \\
86.0 \\
87.5 \\
88.5 \\
90.5 \\
96.0 \\
75.5\end{array}$ & $\begin{array}{r}68 \\
98 \\
69 \\
71 \\
78 \\
81 \\
108 \\
100 \\
85 \\
103 \\
53 \\
99 \\
74\end{array}$ & $\begin{array}{l}128 \\
160 \\
155 \\
138 \\
147 \\
134 \\
151 \\
118 \\
126 \\
127 \\
121 \\
139 \\
149\end{array}$ & $\begin{array}{l}3.41 \\
4.38 \\
5.62 \\
4.11 \\
4.77 \\
4.17 \\
3.79 \\
2.95 \\
3.23 \\
4.08 \\
3.91 \\
4.13 \\
3.86\end{array}$ & $\begin{array}{l}0.83 \\
0.92 \\
0.84 \\
0.89 \\
0.82 \\
0.82 \\
0.83 \\
0.82 \\
0.74 \\
0.81 \\
0.79 \\
0.74 \\
0.71\end{array}$ & $\begin{array}{l}56 \\
61 \\
78 \\
77 \\
65 \\
65 \\
67 \\
68 \\
51 \\
68 \\
72 \\
63 \\
68\end{array}$ & $\begin{array}{l}12 \\
14 \\
17 \\
14 \\
22 \\
17 \\
17 \\
14 \\
10 \\
18 \\
14 \\
18 \\
15\end{array}$ \\
\hline $\begin{array}{l}\text { Average } \\
\text { Standard } \\
\text { deviation }\end{array}$ & $\begin{array}{c}38 \\
\pm 9.1\end{array}$ & 1.77 & 64.5 & \pm 1.0 & \pm 0.7 & \pm 0.40 & \pm 13.2 & \pm 17.0 & \pm 13.7 & \pm 0.64 & \pm 0.05 & \pm 7.6 & \pm 3.02 \\
\hline
\end{tabular}

B. 4 normal males with increased oxygen consumption and/or pulse rate

\begin{tabular}{|c|c|c|c|c|c|c|c|c|c|c|c|c|c|c|}
\hline $\begin{array}{l}\text { L. K. K. } \\
\text { J. K. } \\
\text { J. L. }\end{array}$ & $\begin{array}{l}58 \\
53 \\
39\end{array}$ & $\begin{array}{l}1.60 \\
1.35 \\
1.68\end{array}$ & $\begin{array}{l}54.5 \\
44.0 \\
57.0\end{array}$ & $\begin{array}{l}12.2 \\
13.4 \\
13.7\end{array}$ & $\begin{array}{l}5.2 \\
5.3^{*} \\
4.7\end{array}$ & $\begin{array}{l}2.99 \\
3.10 \\
3.99\end{array}$ & $\begin{array}{r}88.0 \\
95.5 \\
117.5\end{array}$ & $\begin{array}{l}44 \\
35 \\
70\end{array}$ & $\begin{array}{l}155 \\
164 \\
187\end{array}$ & $\begin{array}{l}4.88 \\
8.15 \\
4.84\end{array}$ & $\begin{array}{l}0.94 \\
0.83 \\
0.78\end{array}$ & $\begin{array}{r}108 \\
120 \\
96\end{array}$ & $\begin{array}{l}20 \\
25 \\
12\end{array}$ & $\begin{array}{l}\text { Rapid pulse. } \\
\text { Rapid pulse. } \\
\text { Rapid pulse. Elevated }\end{array}$ \\
\hline D. M. & 40 & 2.00 & 90.0 & 14.9 & $4.8^{*}$ & 3.65 & 81.0 & 107 & 175 & 4.32 & 0.71 & 68 & 15 & $\begin{array}{l}\text { Elevated oxygen con- } \\
\text { sumption. }\end{array}$ \\
\hline Average & 48 & 1.66 & 61.4 & 13.6 & 5.0 & 3.43 & 95.5 & 64 & 170 & 5.55 & 0.82 & 98 & 18 & \\
\hline
\end{tabular}

C. 11 hospital male patients with normal circulation

\begin{tabular}{|c|c|c|c|c|c|c|c|c|c|c|c|c|c|c|}
\hline J. D. & 21 & 1.79 & 62.0 & 14.6 & 4.4 & 2.97 & 86.0 & 63 & 131 & 4.26 & 0.78 & 89 & 22 & Afebrile apical tubercu- \\
\hline N. S. & 38 & 1.67 & 60.0 & 12.5 & 3.6 & 3.01 & 83.5 & 59 & 109 & 3.79 & 1.04 & 85 & 14 & Afebrile apical tubercu- \\
\hline $\begin{array}{l}\text { S. V. } \\
\text { F. M. }\end{array}$ & $\begin{array}{l}37 \\
43\end{array}$ & $\begin{array}{l}1.52 \\
1.93\end{array}$ & $\begin{array}{l}64.0 \\
70.5\end{array}$ & $\begin{array}{l}14.3 \\
11.9\end{array}$ & $\begin{array}{l}4.4 \\
3.5^{*}\end{array}$ & $\begin{array}{l}4.25 \\
3.93\end{array}$ & $\begin{array}{l}100.0 \\
107.5\end{array}$ & $\begin{array}{l}77 \\
95\end{array}$ & $\begin{array}{l}186 \\
137\end{array}$ & $\begin{array}{l}6.11 \\
4.94\end{array}$ & $\begin{array}{l}0.88 \\
0.77\end{array}$ & $\begin{array}{l}83 \\
80\end{array}$ & $\begin{array}{l}18 \\
16\end{array}$ & $\begin{array}{l}\text { Rheumatoid arthritis. } \\
\text { Chr. alcoholism. }\end{array}$ \\
\hline W. H. & 57 & 1.62 & 57.5 & 9.5 & $3.8^{*}$ & 4.05 & 114.0 & 71 & 154 & 6.29 & 0.81 & 92 & 22 & Post pneumonia. \\
\hline $\begin{array}{l}\text { A. V. } \\
\text { T. D. }\end{array}$ & $\begin{array}{l}49 \\
48\end{array}$ & $\begin{array}{l}1.94 \\
1.61\end{array}$ & $\begin{array}{l}71.0 \\
52.0\end{array}$ & $\begin{array}{r}10.8 \\
9.7\end{array}$ & $\begin{array}{l}4.0 \\
4.2 *\end{array}$ & $\begin{array}{l}3.91 \\
3.49\end{array}$ & $\begin{array}{l}107.0 \\
108.0\end{array}$ & $\begin{array}{r}100 \\
56\end{array}$ & $\begin{array}{l}157 \\
147\end{array}$ & $\begin{array}{l}5.71 \\
3.80\end{array}$ & $\begin{array}{l}1.01 \\
0.76\end{array}$ & $\begin{array}{r}76 \\
100\end{array}$ & $\begin{array}{l}13 \\
12\end{array}$ & $\begin{array}{l}\text { Anemia. } \\
\text { Convalescent-Burns. } \\
\text { Convalescent-Skeletal } \\
\text { trauma and anemia. }\end{array}$ \\
\hline P. Y. & 55 & 1.48 & 51.0 & 11.9 & $5.0^{*}$ & 3.93 & 114.0 & 48 & 197 & 6.60 & 0.67 & 120 & 25 & Convalescent-Skeletal \\
\hline J.S. & 45 & 1.74 & 68.0 & 11.0 & $4.6^{*}$ & 3.92 & 100.0 & 97 & 180 & 3.56 & 0.70 & 70 & 8 & $\begin{array}{l}\text { trauma and anemia. } \\
\text { Convalescent-Skeletal }\end{array}$ \\
\hline J. D. & 62 & 1.61 & 57.0 & 9.0 & 5.1 & 3.44 & 97.5 & 63 & 176 & 4.90 & 0.61 & 88 & 18 & $\begin{array}{l}\text { trauma and anemia. } \\
\text { Convalescent - Skeletal }\end{array}$ \\
\hline W. Br. & 46 & 1.83 & 71.0 & 11.7 & 4.2 & 4.03 & 104.0 & 80 & 172 & 5.32 & 0.74 & 92 & 22 & $\begin{array}{l}\text { trauma and anemia. } \\
\text { Convalescent - Skeletal } \\
\text { trauma and anemia. }\end{array}$ \\
\hline Average & 46 & 1.70 & 62.2 & 11.5 & 4.3 & 3.72 & 101.9 & 74 & 159 & 5.03 & 0.80 & 89 & 17 & \\
\hline
\end{tabular}

D. 6 hospital female patients with normal circulation

\begin{tabular}{|c|c|c|c|c|c|c|c|c|c|c|c|c|c|c|}
\hline D. L. & 32 & 1.54 & 55.5 & 12.8 & 3.6 & 2.60 & 72.0 & 43 & 112 & 3.35 & 0.76 & 112 & 18 & Afebrile apical tubercu- \\
\hline M. Mc. & 32 & 1.43 & 48.5 & 11.3 & 4.2 & 2.93 & 84.5 & 50 & 123 & 4.47 & 0.79 & 84 & 18 & Afebrile apical tubercu- \\
\hline $\begin{array}{l}\text { F. } \mathbf{~ K} \text {. } \\
\text { J. C. }\end{array}$ & $\begin{array}{l}33 \\
56\end{array}$ & $\begin{array}{l}1.60 \\
1.42\end{array}$ & $\begin{array}{l}56.0 \\
47.5\end{array}$ & $\begin{array}{r}12.2 \\
9.9\end{array}$ & $\begin{array}{l}4.0^{*} \\
3.6^{*}\end{array}$ & $\begin{array}{l}2.34 \\
3.32\end{array}$ & $\begin{array}{l}67.0 \\
98.5\end{array}$ & $\begin{array}{l}65 \\
59\end{array}$ & $\begin{array}{r}94 \\
120\end{array}$ & $\begin{array}{l}3.34 \\
2.81\end{array}$ & $\begin{array}{l}0.77 \\
0.69\end{array}$ & $\begin{array}{l}58 \\
80\end{array}$ & $\begin{array}{l}12 \\
14\end{array}$ & $\begin{array}{l}\text { losis and anemia. } \\
\text { Minimal tuberculosis. } \\
\text { Chr. alcoholism. }\end{array}$ \\
\hline ‥ & $\begin{array}{l}22 \\
48\end{array}$ & $\begin{array}{l}1.63 \\
1.42\end{array}$ & $\begin{array}{l}59.5 \\
42.0\end{array}$ & $\begin{array}{l}10.6 \\
11.9\end{array}$ & $\begin{array}{l}4.7^{*} \\
3.5\end{array}$ & $\begin{array}{l}2.64 \\
4.13\end{array}$ & $\begin{array}{r}72.5 \\
143.0\end{array}$ & $\begin{array}{l}60 \\
66\end{array}$ & $\begin{array}{l}124 \\
145\end{array}$ & $\begin{array}{l}4.36 \\
4.81\end{array}$ & $\begin{array}{l}0.83 \\
0.73\end{array}$ & $\begin{array}{l}72 \\
92\end{array}$ & $\begin{array}{l}18 \\
18\end{array}$ & $\begin{array}{l}\text { Anterma. } \\
\text { Post skescent-Anemia. Anem. trauma. } \\
\text { Convalescent anemia. }\end{array}$ \\
\hline Average & 37 & 1.51 & 51.5 & 11.5 & 3.9 & 2.99 & 89.6 & 57 & 120 & 3.87 & 0.73 & 83 & 16 & \\
\hline $\begin{array}{l}\text { Average } \\
\text { all } 34 \\
\text { cases }\end{array}$ & 42 & 1.69 & 61.0 & 12.8 & 4.5 & 3.32 & 89.0 & 73 & 145 & 4.51 & 0.81 & 82 & 17 & \\
\hline
\end{tabular}

* Mixed venous samples from right ventricle. 

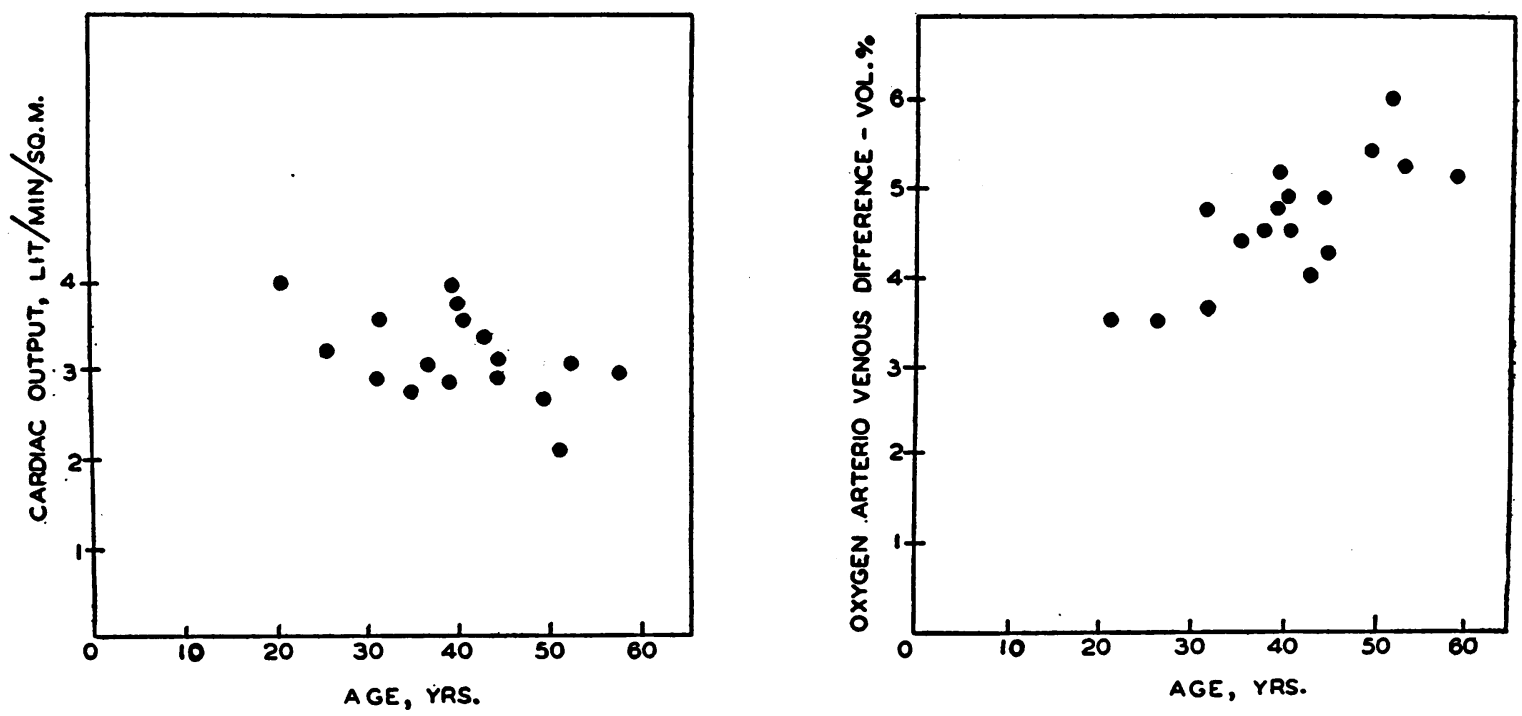

Fig. 2. Scatter Diagrams Showing Correlation Between Cardiac Index and Age, on the left; and Oxygen Arterio-Venous Difference and Age, on the right

measurements related to cardiac output under basal conditions in healthy males. The hospitalized subjects in the table are separated into 2 groups according to sex (Table II).

The data obtained on the 13 normal male subjects reveal the following: (1) The average values for $\mathrm{O}_{2}$ arterio-venous difference, and of cardiac output in liters per minute per square meter of body surface are higher than the accepted figures for these measurements based on foreign gas methods of cardiac output determination. (2) There is an apparently signifcant influence of age upon oxygen arterio-venous difference and upon cardiac output; this is illustrated in the 2 scatter diagrams of Figure 2.
The data on the hospital patients show: (1) in the male group, larger average figures for cardiac output than in the healthy male group and slightly lower figures for stroke volume, this increase associated with faster pulse rate and larger oxygen consumption with little change in arterio-venous difference; (2) in the female group, a lower average figure for arterio-venous difference, cardiac index, stroke volume, and oxygen consumption, with a more rapid pulse rate than in the healthy male group.

For purposes of comparison, the figures of cardiac output determinations by the ethyl iodide method, carried out on a group of normal individuals similar to our 13 normal male sub-

TABLE III

Statistics of cardiac output measured by 3 methods in 3 different groups of normal healthy males under basal conditions

\begin{tabular}{|c|c|c|c|c|c|c|c|c|}
\hline & \multicolumn{2}{|c|}{$\begin{array}{l}\text { Starr et al. } \\
\text { Ethyl iodide } \\
21 \text { cases }\end{array}$} & \multicolumn{2}{|c|}{$\begin{array}{l}\text { Nylin } \\
\text { Acetylene } \\
19 \text { cases }\end{array}$} & \multicolumn{2}{|c|}{$\begin{array}{l}\text { Cournand et al. } \\
\text { "Direct Fick" } \\
13 \text { cases }\end{array}$} & \multicolumn{2}{|c|}{$\begin{array}{l}\text { Significance of } \\
\text { difference between } \\
\text { means in groups: }\end{array}$} \\
\hline & \multirow{2}{*}{ Mean } & \multirow{2}{*}{$\begin{array}{c}\text { St. } \\
\text { devia- } \\
\text { tion }\end{array}$} & \multirow{2}{*}{ Mean } & \multirow{2}{*}{$\begin{array}{l}\text { St. } \\
\text { devia- } \\
\text { tion }\end{array}$} & \multirow{2}{*}{ Mean } & \multirow{2}{*}{ 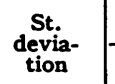 } & $1-3$ & $2-3$ \\
\hline & & & & & & & $P$ & $P$ \\
\hline $\begin{array}{l}\text { Age, years } \\
\text { Body surface area, sq. m. } \\
\text { Pulse rate } \\
\mathrm{O}_{2} \text { intake, ml. per min. per sq. m. } \\
\mathrm{O}_{2} \text { arterio-venous diff., volumes per cent } \\
\text { Cardiac output, } L \text {. per min. per sq. } m \text {. } \\
\text { Stroke volume, ml. per beat }\end{array}$ & $\begin{array}{c}32.8 \\
1.84 \\
65 \\
130 \\
5.5 \\
2.45 \\
72\end{array}$ & $\begin{array}{l} \pm 8.7 \\
\pm 0.14 \\
\pm 9 \\
\pm 18 \\
\pm 1.4 \\
\pm 0.50 \\
\pm 20\end{array}$ & $\begin{array}{l}1.79 \\
71 \\
132 \\
5.5 \\
2.46 \\
64\end{array}$ & $\begin{array}{l} \pm 0.15 \\
\pm 10 \\
\pm 14 \\
\pm 0.7 \\
\pm 0.37 \\
\pm 13\end{array}$ & $\begin{array}{c}39 \\
1.77 \\
66 \\
138 \\
4.5 \\
3.12 \\
84\end{array}$ & $\begin{array}{l} \pm 9.1 \\
\pm 0.19 \\
\pm 8 \\
\pm 14 \\
\pm 0.7 \\
\pm 0.40 \\
\pm 17\end{array}$ & $\begin{array}{c}>0.05 \\
>0.10 \\
>0.10 \\
>0.10 \\
>0.01<0.02 \\
<0.0004 \\
>0.05\end{array}$ & $\begin{array}{l}>0.10 \\
>0.10 \\
>0.10 \\
<0.0004 \\
<0.0004 \\
<0.0004\end{array}$ \\
\hline
\end{tabular}

$P$ is the probability that the difference would appear by chance and is expressed as a decimal factor (1.00 is 100 per cent probability). 
jects, have been taken from published data (3), and a comparable set of figures of cardiac output by the acetylene method (4). The 2 sets of figures are compared statistically with our data in Table III.
As the table shows, the 3 groups were similar so far as concerns age, body size, pulse rate, and oxygen consumption.

Cardiac output, however, is significantly larger by our direct Fick-technique than by either the

TABLE IV

Repeated measurement of the circulation on two normal individuals at various intervals

\begin{tabular}{|c|c|c|c|c|c|c|c|c|}
\hline Patient & \multicolumn{6}{|c|}{ I. M. 44} & \multicolumn{2}{|c|}{ P. H. 54} \\
\hline Date & $2-3-43$ & $2-3-43$ & $2-11-43$ & $2-11-43$ & $7-22-43$ & $7-29-43$ & $2-18-41$ & $7-26-43$ \\
\hline $\begin{array}{l}\mathrm{O}_{2} \text { consumption, ml. per min. per sq. } m . \\
\text { Heart rate } \\
\text { Cardiac index, L. per min. per sq. } m . \\
\text { Stroke volume, ml. per beat } \\
\text { Arterio-venous difference, ml. per } L . \text { blood }\end{array}$ & $\begin{array}{c}144 \\
51 \\
3.13 \\
91 \\
4.6^{*}\end{array}$ & $\begin{array}{c}2 \text { hrs. } \\
\text { later } \\
126 \\
51 \\
2.93 \\
85 \\
4.3^{*}\end{array}$ & $\begin{array}{l}131 \\
57 \\
3.28 \\
84 \\
4.0^{*}\end{array}$ & $\begin{array}{c}2 \mathrm{hrs} . \\
\text { later } \\
128 \\
56 \\
3.21 \\
83 \\
4.0^{*}\end{array}$ & $\begin{array}{c}115 \\
64 \\
3.13 \\
72 \\
3.7\end{array}$ & $\begin{array}{c}122 \\
62 \\
2.85 \\
68 \\
4.3\end{array}$ & $\begin{array}{l}128 \\
56 \\
2.12 \\
68 \\
6.0\end{array}$ & $\begin{array}{l}115 \\
56 \\
2.31 \\
74 \\
5.0\end{array}$ \\
\hline
\end{tabular}

* Mixed venous blood sample from the right ventricle.

TABLE V

State of respiratory gases in mixed venous and arterial blood in 33 "hospital normal" subjects

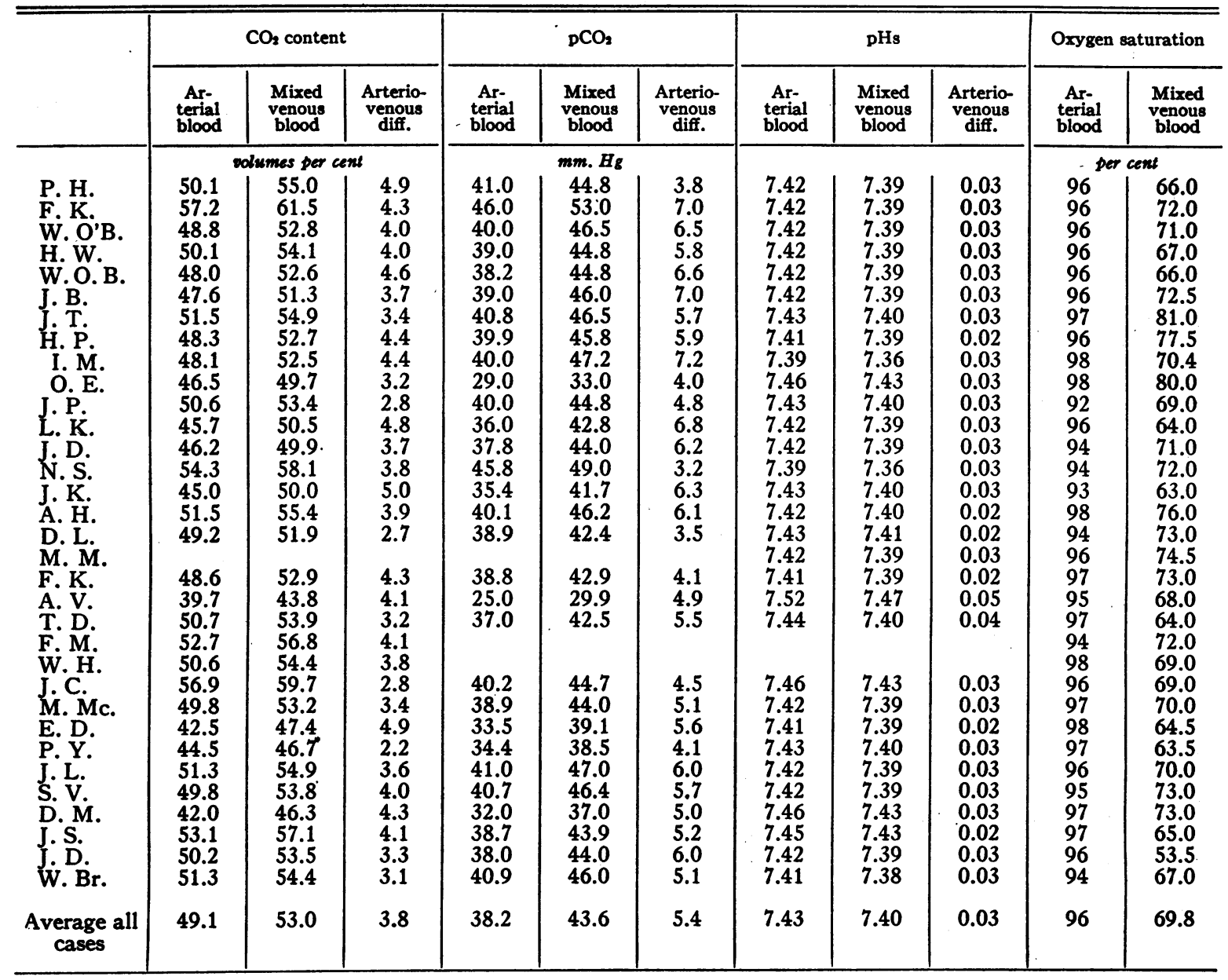


ethyl iodide or the acetylene methods. The oxygen arterio-venous difference by the direct Fick method is correspondingly smaller, though the comparison with the ethyl iodide method shows here a lesser significance because of the large scatter in the latter measurements and therefore larger standard deviation.

The average cardiac index by the direct Fick technique, 3.12 liters per minute per square meter body surface, is 26.8 per cent above the average by the 2 foreign gas methods. Cardiac outputs by the direct Fick technique and by the ballistocardiograph (5) have recently been compared (6), the two measurements being carried out on the individual subjects practically simultaneously. The ballistocardiograph gives results closely similar to the ethyl iodide method. The comparison showed the average cardiac output (fourteen measurements) by the direct Fick technique to be 18.5 per cent higher than by the ballistocardiograph.

Further comparison of "direct" and "indirect" methods should be made by simultaneous measurements on the same individuals.

Two additional points may be mentioned relative to the reliability of our present techniques. (a) In 14 pairs of duplicate determinations, each duplicate set carried out within onehalf hour, the average deviation from the mean was 2.6 per cent, with a range from 0.4 to 6.0 per cent. (b) On subject I. M., a normal control, 6 separate determinations were made, the final 2 being carried out 5 months after the first, and by a different research team (results kindly communicated by Dr. Herbert Chasis of New York University). The constancy of the findings is shown in Table IV. A similar comparison of results 5 months apart, is given in Table IV for subject P. H., another normal control. Dr. Chasis also made the second of these determinations. This subject had the lowest cardiac index of all the normal control subjects.

\section{$K$. State of respiratory gases in mixed venous blood and arterial blood in 33 normal and "hospital normal" subjects}

In 33 out of the 34 cases previously mentioned, $\mathrm{pH}$, determinations on mixed venous blood and arterial blood samples were made with a glass electrode, and Rockefeller Institute type of potentiometer, in addition to determinations of $\mathrm{CO}_{2}$ and $\mathrm{O}_{2}$ content and $\mathrm{O}_{2}$ capacity. By using the Van Slyke et al. and the Dill et al. normograms, $\mathrm{pCO}_{2}$ was then calculated. A complete picture of the state of the respiratory gases in mixed venous blood and arterial blood was thus obtained. Direct measurements of simultaneous samples of arterial and mixed venous blood, in normal subjects, have not previously been reported (Table V).

\section{Summary}

1. A method of measurement of cardiac output in man, by the "direct Fick" principle, using the technique of catheterization of the right auricle or right ventricle, is described in detail. The validity of the method is discussed.

2. More than 260 catheterizations of the right heart have been carried out with no unfavorable complication other than linear thrombus formation at times near the site of insertion of the catheter in the brachial vein.

3. In a group of 13 normal healthy males, the average cardiac index (cardiac output in liters per minute per square meter of body surface) was 3.12. This figure is 26.8 per cent higher than the average values for cardiac index from comparable groups of normal subjects by the ethyl iodide and by the acetylene methods.

4. Measurements of cardiac output and of the respiratory gases in arterial and mixed venous blood are reported on a total of 34 normal and "hospital normal" subjects.

\section{BIBLIOGRAPHY}

1. Cournand, A., and Ranges, H. A., Catheterization of the right auricle in man. Proc. Soc. Exper. Biol. and Med., 1941, 46, 462.

2. Holt, J. P., and Knoefel, P. K., The oxygen content of blood in right auricle and right ventricle. Federation Proceedings: American Physiological Society, 1944.

3. Starr, I., Jr., Collins, L. H., Jr., and Wood, F. C., Studies of the basal work and output of the heart in clinical conditions. J. Clin. Invest., 1933, 12, 13.

Starr, I., Jr., Donal, J. S., Margolies, A., Shaw, R., Collins, L. H., and Gamble, C. J., Studies of the heart and circulation in disease; estimations of basal cardiac output, metabolism, heart size, and blood 
pressure in 235 subjects. J. Clin. Invest., 1934, $13,561$.

4. Nylin, G., Clinical tests of the function of the heart. Acta Med. Scandinav., 1933, supp. 52, 1.

5. Starr, I., and Schroeder, H. A., Ballistocardiogram. II. Normal standards, abnormalities commonly found in diseases of the heart and circulation, and their significance. J. Clin. Invest., 1940, 19, 437.

6. Cournand, A., Ranges, H. A., and Riley, R. L., Comparison of results of the normal ballistocardiogram and a direct Fick method in measuring the cardiac output in man. J. Clin. Invest., 1942, 21, 287. 